\title{
Attitude of Undergraduate Students towards Gamification: A Case Study of Northwest Geo-Political Zone, Nigeria
}

\author{
Sikap Pelajar Pra Siswazah terhadap Gamifikasi: \\ Satu Kajian Kes di Zon Geo-Politik Barat Utara, Nigeria
}

\author{
Auwalu Rabiu Ali ${ }^{1}$, Azizah Endut ${ }^{2}$, Rahimah Embong ${ }^{3}$ \\ ${ }^{1}$ Institut Penyelidikan Alam Sekitar Pantai Timur (ESERI), Universiti Sultan Zainal Abidin, Terengganu, Malaysia; \\ auwalurabiualirano@gmail.com \\ ${ }^{2,3}$ Faculty of Innovative Design \& Technology, Universiti Sultan Zainal Abidin, Terengganu, Malaysia; \\ \{enazizah, rahimahembong@unisza.edu.my\}
}

\begin{abstract}
Gamification of education is new field in education that is attracting researchers who are passionate on education. However, no much researches were made to assess the users' perception on its application in enhancing students understanding of certain subjects such as Environmental Education. This article is aimed at assessing the students' attitude on the application of eeGamification in environmental education. The method employed was survey method. A structured questionnaire was used and a total of 372 respondents were used in the study. The survey employed descriptive statistics analysis to measure the level of students' attitude towards eeGamification. The result indicates that students have positive attitude towards gamification. This shows that students accept the idea of gamification in improving students' understanding of Environmental Education.
\end{abstract}

Keywords: Gamification, environmental, awareness, knowledge, attitude.

\begin{abstract}
Abstrak
Gamifikasi dalam pendidikan merupakan bidang baharu dalam pendidikan yang menarik penyelidik yang berminat dalam pendidikan. Namun, kurang penyelidikan dilakukan dalam menilai penerimaan pengguna terhadap aplikasinya dalam meningkatkan pemahaman pelajar terhadap mata pelajaran tertentu seperti Pendidikan Persekitaran. Artikel ini menumpukan kepada mengukur sikap pelajar terhadap aplikasi eeGamification dalam pendidikan persekitaran. Kaedah yang digunakan adalah kaedah tinjauan. Satu soal-selidik berstruktur telah digunakan dan sejumlah 372 orang responden telah terlibat dalam kajian ini. Tinjauan menggunakan analisa statistik deskriptif digunakan untuk mengukur tahap sikap pelajar terhadap eeGamification. Hasil menunjukkan pelajar mempunyai sikap positif terhadap gamifikasi. Ini menunjukkan pelajar menerima idea gamifikasi dalam memperbaiki pemahaman pelajar terhadap Pendidikan Persekitaran.
\end{abstract}

Kata kunci: Gamifikasi, persekitaran, kesedaran, pengetahuan, sikap. 


\section{INTRODUCTION}

During the last couple of years, gamification has been a trending topic and a subject to much hype as a means of supporting user engagement and enhancing positive patterns in service use, such as increasing user activity, social interaction, or quality and productivity of actions These desired use patterns are considered to emerge as a result of positive, intrinsically motivating, gameful experiences brought about by game/motivational affordances implemented into a service.

The popular interest in gamification is also reflected in an academic context: the number of papers published on gamification is growing. It is especially noteworthy that the appearance of the term "gamification" in paper titles has been increasing even more rapidly than general search hits. This suggests that gamification is becoming a more popular subject for academic inquiry. Despite the rapid interest of using gamification in academic context, there is a need to determine the attitude of students towards gamification. This will reflect the user experience gained through gamification and the need to make adjustment in the area of gamification so that it can be more academically acceptable and recognized as the next method of imparting knowledge to the learners through increasing user engagement brought about by gameful experiences.

Attitude of students towards the eeGamification as in the context of this paper refers to the character or behaviour that the player acquired in the process of engaging him/her self with the game. This attitude is what brings positive changes in the students' belief and conception about the eeGamification and it also highlights the students' acceptability of whether the gamification idea will promote their level of understanding of the environment.

\section{METHODOLOGY}

A quantitative research approach was adapted for the present study. The method applied was survey approach where the students were presented with a questionnaire to responds their thought regarding the application of gamification in Environmental Education. The location of the study is Northwest zone states of Nigeria. The zone is characterized by rapid desert encroachment and pronounced deforestation. The people in the zone relied solely on firewood as their main source of energy. The researcher attempts to foster environmental awareness in the region first uses gamification. It was done through the application of eeGamification by the students to booster their understanding of the environment. The justification for selecting this zone is that the researchers want to assess the students' perception on the application of gamification in the Northwest universities zone as a new means of creating environmental awareness in the region. Six universities were selected for the study and a total of 372 students were drawn from these universities as samples of the study. The questionnaire used to collect the data contains 10 items rating on a three Likert scale ( $1=$ Disagree, $2=$ Unsure, $3=$ Agree $)$. The collected data was analysed using SPSS version 20. The statistical technique used was simple mean and SD, and percentages. 


\section{RESULTS}

\section{Students Attitude}

As mentioned, this study was conducted at northwest geopolitical region's universities in Nigeria. A eeGamification Satisfactory Scale (GSS) was used to measure undergraduate students' attitude towards using eeGamification. The measurement was done focusing on environmental awareness, knowledge, and attitude. The scale was calculated to have a reliability value of 0.7 , which is considered enough to predict test or to measure hypothesis is seconded by Nunnally (1978).

Table 1 shows the satisfaction mean scores of the respondents in expressing their satisfaction using eeGamification. Data shows that their environmental awareness, knowledge, and attitude was significantly high $(\mathrm{M}=2.12, \mathrm{SD}=0.38)$.

Table 1: Satisfaction Mean Scores of Undergraduate Students towards using eeGamification

\begin{tabular}{lcccc}
\hline \multirow{2}{*}{ General Mean Satisfaction Score of Undergraduate Students } & $\mathrm{N}$ & Mean & Standard Deviation \\
\cline { 2 - 4 } & 372 & 2.12 & 0.38 \\
\hline
\end{tabular}

Table 2 shows a detailed analysis of the results by looking at the items response based on the available options on the Likert scale. While in Table 3, the mean and SD scored for each item were depicted. From the Table 2, 47.8\% of the respondents agreed that the eeGamification content were efficiently well-presented. It shows that the eeGamification was designed mainly to promote the awareness, knowledge, and attitude of students towards the environment. Next, $70.9 \%$ of the respondents agreed eeGamification was easy to work with and $60.4 \%$ enjoyed the experience gained during the intervention. The results also showed that $54.9 \%$ of the respondents said the learning experience was worthwhile and 59.3\% said they learned about the course topic with the tool. However, only $24.2 \%$ agreed that the functions and practical activities of the eeGamification were useful. Nevertheless, majority of the respondents $(49.5 \%)$ agreed that there were enough stuff and activities in the eeGamification, and majority (32.4\%) agreed that they were involved. Also, form the result below; majority $(45.1 \%)$ wants to learn about the topic.

Table 2 Scale Items Descriptive Statistics of Attitude of Undergraduate Students towards eeGamification

\begin{tabular}{clccc}
\hline \multirow{2}{*}{ S. No. } & \multirow{2}{*}{ Items } & \multicolumn{3}{c}{ Percentages (\%) } \\
\cline { 3 - 5 } & & Disagree & Unsure & Agree \\
\hline 1 & Content was efficiently presented & 38.5 & 13.7 & 47.8 \\
2 & I want to learn about the topic & 35.2 & 19.8 & 45.1 \\
3 & I enjoyed the experience & 19.8 & 19.8 & 60.4 \\
4 & The tool was easy to use & 14.8 & 14.3 & 70.9 \\
5 & Learning experience was worthwhile & 23.1 & 22.0 & 54.9 \\
6 & There was sufficient number of stuff and activities & 40.7 & 9.9 & 49.5 \\
7 & Time to complete the activities was enough & 32.4 & 19.2 & 48.4 \\
8 & I was involved & 51.6 & 15.9 & 32.4 \\
9 & I learned about the course topic with the tool & 24.2 & 16.5 & 59.3 \\
10 & The functions and practical activities were useful & 63.2 & 12.6 & 24.2 \\
\hline
\end{tabular}




\section{Students Level of Satisfaction}

An attitudinal survey was conducted on the experimental group to evaluate students' level of satisfaction and their attitude towards the eeGamification tool. A three-point Likert scale questionnaire with all questions scored on a positive scale was used. Answers were anonymous. 182 students of the intervention group provided feedback because the instrument was given to the participants along with the post-intervention questionnaire.

Moreover, questions and results are presented in Table 3. The average was 2.15 for the eeGamification, indicating that students' attitudes towards both experiences were positive. The highest rated items for the intervention were items $1,2,3,4,5,6,7$, and 9 suggesting that contents were properly designed in an easy-to-use and useful manner. It also suggests that the experience in the intervention was fascinating that students have learned about the course topic and hence students are willing to further learn about the topic. The time to complete the activities was adequate according to students' perception. Results are opposite for the items 8 and 10 were the lowest rated indicating low involvement of students with the eeGamification.

Table 3 Attitudinal Survey and Results for the Treatment Group $(\mathrm{N}=182)$

\begin{tabular}{clcc}
\hline S. No. & \multicolumn{1}{c}{ Items } & Mean & SD \\
\hline 1 & Content was efficiently presented & 2.09 & 0.93 \\
2 & I want to learn about the topic & 2.10 & 0.89 \\
3 & I enjoyed the experience & 2.41 & 0.80 \\
4 & The tool was easy to use & 2.56 & 0.74 \\
5 & Learning experience was worthwhile & 2.32 & 0.83 \\
6 & There was sufficient number of stuff and activities & 2.09 & 0.95 \\
7 & Time to complete the activities was enough & 2.16 & 0.89 \\
8 & I was involved & 1.81 & 0.89 \\
9 & I learned about the course topic with the tool & 2.35 & 0.85 \\
10 & The functions and practical activities were useful & 1.61 & 0.85 \\
\hline
\end{tabular}

\section{DISCUSSION}

The attitude of students was positive. According to majority of scholars (Hamari et al., 2014), gamification does produce positive effects and benefits. Student's perceptions of the use of eeGamification in environmental education indicated that the content was useful and efficiently presented and that the tool was easy to use. Furthermore, the students found that there were enough materials available and were satisfied with the number of activities and the time allowed to complete them and that there was not enough time to complete the exercises.

However, the respondents acknowledged having a low involvement rate. Gamification seems to be not promising in this respect, but the bottom line is, in the researcher's opinion, that a thorough instructional design driven by clear objectives is essential for a meaningful integration of gamification in e-learning approaches. Specifically, in the same way that the motto "built it and they will come and learn" proves to be wrong for e learning (Zemsky \& Massy, 2004). Similar sayings like "socialize it, 
and they will participate" or "gamify it, and they will be motivated" seem to be equally flawed just because they are ignoring the necessity of an underlying sound pedagogy.

Low participation rate is a major concern in our opinion. Lecturers established benchmarks of what represented a reasonable participation threshold, which was roughly a $20 \%$ of active engagement with the course materials and completion of the optional activities. Under this premise, the researcher found that 59 out of $182(32.4 \%)$ students actively engaged with the gamification plugin. de-Marcos et al. (2014) revealed that students have a positive attitude towards gamification. The results are similar to study conducted by Uzunboylu et al. (2009), where students show satisfaction with using mobile learning technology to facilitate environmental awareness among them. However, gamification might not be effective all the time (Hamari, 2013 and Jung et al., 2010), but several factors such as the nature of the gamified system and user's motivation (Hamari, \& Tuunanen, 2013) is defended upon the engagement brought by gamification.

\section{CONCLUSION}

Students' attitude towards the application of gamification in fostering environmental awareness, knowledge, and attitude was found positive and encouraging. Moreover, students show their good perception and confirm that eeGamification is enough to booster environmental awareness, knowledge, and attitude. Students, moreover, showed that the contents were effectively presented and that is what makes it easy to learn. The students presented that the learning experiences were worthwhile and therefore they have enjoyed the experience acquired. That is what is expected from learning through gamification and gives a wide barrier of difficulties in terms of learning smoothness compared to the traditional or conventional teaching and learning approaches. It is therefore recommended for use in our universities.

\section{REFERENCES}

de-Marcos, L., Dominguez, A., \& Saenz-Navarrete, S. (2014). An empirical study comparing gamification and social networking on e-learning. Computers and Education, 75, 82-91.

Hamari, J. (2013). Transforming Homo Economicus into Homo Ludens: A field experiment on gamification in a utilitarian peerto-peer trading service. Electronic Commerce Research and Applications, 12(4), 236- 245.

Hamari, J. \& Tuunanen, J. (2013). Player Types: A Meta- synthesis, Transactions of the Digital Games Research Association, $1(2)$.

Hamari, J., Koivisto, J., \& Sarsa, H. (2014). Does gamification work? - A literature review of empirical studies on gamification. A paper presented at the 47th Hawaii International Conference on System Science, 3025-3034.

Jung, J. H., Schneider, C., \& Valacich, J. (2010). Enhancing the motivational affordance of information systems: The effects of real-time performance feedback and goal setting in group collaboration environments. Management Science, 56(4), 724 742.

Nunnally, J. C. (1978). Psychometric Theory. New York: McGraw-Hill Book Company.

Uzunboylu, H., Cavus, N., \& Ercag, E. (2009). Using mobile learning to increase environmental awareness. Computers and Education, 52(2), 381-389.

Zemsky, R. \& Massy, W. F. (2004). Thwarted innovation: What happened to e-learning and why. Pennsylvania: The Learning Alliance at the University of Pennsylvania. 